\title{
Phlebotomine sand flies on the crossroads of Anatolia: transmitted diseases and vectors
}

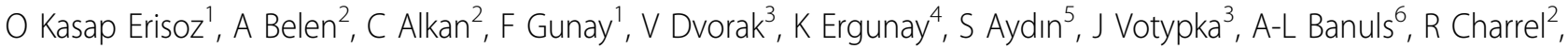 \\ A Özkul ${ }^{7}, Y$ Özbel $^{8}$, P Volf ${ }^{3}$, B Alten $^{1 *}$ \\ From The 1st Conference on Neglected Vectors and Vector-Borne Diseases (EurNegVec): with Management \\ Committee and Working Group Meetings of the COST Action TD1303 \\ Cluj-Napoca, Romania. 8-11 April 2014
}

The Western Palearctic (WP) is composed of Europe, Middle East and North Africa. In this territory, the Mediterranean Sea, and the land under the influence of the Mediterranean Sea is the most important geographical character for both migration and dispersion of organisms; especially for invertebrates including sand flies. Anatolia (Asia-Minor) takes place on the crossroads of this area and these events.

The phlebotomine sand flies (Diptera: Psychodidae, Phlebotominae) are vectors of several infectious pathogens causing leishmaniases and arbovirus infections due to phleboviruses. Several of these diseases have wide geographical distributions in the WP, and give rise to occasional epidemic outbreaks. In numerous countries, increasing risk factors are making sand fly-borne diseases a major public and veterinary health problem. Many studies on phylogenetic relationship among sand fly taxa, their distribution, population structure and diseases of phlebotomine species have been already published, but there are still many gaps waiting to be filled up in, especially, Anatolia. In this point, scientists have to discuss some deficiencies under cover of geography, history and phylogenetic studies to understand the mechanisms of distribution of both sand fly species and their pathogens in Anatolia.

In this presentation, updates in distribution of sand fly species with state of art maps of EU-VBORNET project, possible new species, leishmaniasis and phleboviruses epidemiology will be discussed with an emphasis on several studies performed by our group between 2000 and present in Anatolia.

\footnotetext{
* Correspondence: kaynas@hacettepe.edu.tr

${ }^{1}$ Faculty of Science, Hacettepe University, Department of Biology, Ecology Section, Beytepe-Ankara-Turkey

Full list of author information is available at the end of the article
}

Studies were supported by EU-FP7 Edenext project, HU-Scientific Research Foundation and Turkish Scientific and Technical Research Council.

\begin{abstract}
Authors' details
${ }^{1}$ Faculty of Science, Hacettepe University, Department of Biology, Ecology Section, Beytepe-Ankara-Turkey. ${ }^{2}$ Unite des Virus Emergents, Marseille Universite, UMR190 “Emergence des Pathologies Virales, Faculte de Medecine, Marseille, France. ${ }^{3}$ Parasitology Department, Charles University, Faculty of Science, Prague, Czech Republic. ${ }^{4}$ Department of Medical Microbiology, Hacettepe University, Faculty of Medicine, Virology Unit, Sihhiye-Ankara-Turkey. ${ }^{5}$ Department of Communication Sciences, Hacettepe University, Faculty of Communication, Beytepe-Ankara-Turkey. ${ }^{6}$ RDD (IRD 224CNRS 5290-UM1-UM2), MIVEGEC, Montpellier, France. ${ }^{7}$ Department of Virology, Ankara University, Faculty of Veterinary Medicine, Diskapi-AnkaraTurkey. ${ }^{8}$ Parasitology Department, Ege University, Faculty of Medicine, Bornova, Izmir, Turkey.
\end{abstract}

Published: 1 April 2014

doi:10.1186/1756-3305-7-S1-021

Cite this article as: Kasap Erisoz et al:: Phlebotomine sand flies on the crossroads of Anatolia: transmitted diseases and vectors. Parasites \& Vectors 2014 7(Suppl 1):O21.

Submit your next manuscript to BioMed Central and take full advantage of:

- Convenient online submission

- Thorough peer review

- No space constraints or color figure charges

- Immediate publication on acceptance

- Inclusion in PubMed, CAS, Scopus and Google Scholar

- Research which is freely available for redistribution

Submit your manuscript at www.biomedcentral.com/submit 